\title{
Adoption Levels of Cocoa Rehabilitation Programmes in South-west Nigeria
}

\author{
Akinnagbe Oluwole Matthew ${ }^{1 *}$ \\ ${ }^{1)}$ Department of Agricultural Extension \& Communication Technology, \\ Federal University of Technology, Akure, Ondo State, Nigeria. \\ ${ }^{*}$ Corresponding author : omakinnagbe@futa.edu.ng \\ Received: 24 February 2020 / Accepted: 26 March 2020
}

\begin{abstract}
Cocoa is an important crop to the economies of countries such as Nigeria, Cote D'Ivoire, Ghana and Cameroon in West Africa. In an effort to revive cocoa sector and increase cocoa production in Nigeria led to cocoa rehabilitation programme (CRPs) by the Federal Government of Nigeria. This study ascertained the adoption levels of farmers in cocoa rehabilitation programmes in South-west Nigeria. Data for the study were collected from 240 cocoa farmers through the use of interview schedule and focus group discussion. Multistage sampling procedure was used in selecting respondents. Data were analysed using percentage and mean statistics. Results revealed that, adoption level was low for coppicing techniques $(38.0 \%, 32.0 \%$ and $33.0 \%)$ and complete replanting $(25.0 \%, 27.0 \%$ and $26.0 \%$ ) of cocoa rehabilitation programme, respectively, for the three groups of farmers (farmers that benefitted from government agency cocoa resuscitation programme, farmers that benefitted from non-governmental agency cocoa resuscitation programme and farmers that benefitted from both governmental and nongovernmental agencies). Planting of young cocoa seedling under old cocoa trees $(98 \%, 94 \%, 95 \%)$ and selective planting/gapping up $(68.0 \%, 81.0 \%$ and $79.0 \%)$ had a very high adoption level for the three groups of the farmers. The most helpful agency in the adoption of cocoa resuscitation programmes was Agricultural Development Programme. To improve the level of adoption of cocoa resuscitation programmes, the federal government of Nigeria should further intensify efforts in encouraging more farmers in cocoa rehabilitation programme by providing the necessary incentives (like distribution of free cocoa seedlings) to the farmers as at when necessary.
\end{abstract}

Keywords: Adoption, cocoa, resuscitation programmes, farmers, Nigeria

\section{INTRODUCTION}

Cacao (Theobroma cacao), is an important cash crop, providing income to more than 4.5 million families worldwide. It is the source of chocolate, one of the world's most popular foods (Adeniyi, 2019; Schroth et al., 2017). Africa is the largest producer of cocoa, accounting for $66.8 \%$ of the total global production followed by Latin America and the Asia Pacific. Europe is the largest consumer and importer followed by North America. The major cocoa bean exporting countries include Cote d'Ivoire, Ghana, Nigeria, Cameroon, Brazil, Ecuador, Colombia, Indonesia and, Malaysia among others. Although the production of cocoa beans is dominated in Africa, Latin America and Asia Pacific; the major grinding facilities are placed in the Americas and Europe (FAO, 2017). 
In the year 2017, the global cocoa production statistics showed that, Ivory Coast is by far the largest cocoa producing country in the world supplying over $30 \%$ of the world's cocoa beans at 2,034,000 tonnes. Ghana is the second biggest cocoa producing country in the world with 883,652 tonnes, Indonesia is the third biggest cocoa producer in the world, despite the fact they hardly grew cocoa before the 1980s. Indonesia produced 659,776 tonnes of cocoa in 2017. Nigeria is in the fourth position and produced 328,263 tonnes of cocoa, while Cameroon is the fifth largest producing country in this region with 295,028 tonnes (FAO, 2017; Camargo \& Nhantumbo, 2016).

Nigeria is used to be the second biggest producer of cocoa in the World pre-1970, but this declined with the discovery of large amounts of crude oil. The country has suffered heavily with the fact they have old cocoa trees, ageing farmers, low yields and a lack of cocoa knowledge among farmers. Nigeria total production in 2017 (328,263 tonnes) only represent around 2 percent of the country's exports. Looking positively, the country has shifted its attention back to cocoa cultivation and they still have the available land and climate to reinvigorate the industry and to revive their economy. The Nigerian government in 1999 in an effort to increase national output established Cocoa Resuscitation Programme (CRP) which was executed by the National Cocoa Development Committee (NCDC) for producing states with a view to rehabilitating old farms and improve the country's production. In response to this development Cocoa Research Institute of Nigeria (CRIN) developed various cocoa rehabilitation techniques (CRTs) for the purpose of regenerating old cocoa trees on cocoa plantation in Nigeria. To achieve this, CRIN considered information transfer on CRTs a significant approach through the collaboration of other organisations in Nigeria
(Adeogun et al., 2010). The various cocoa rehabilitation techniques are coppicing, phase replanting, gapping up, etc, to encourage old cocoa trees to become more productive. The questions now relate to the levels of adoption of various cocoa rehabilitation techniques introduced to the farmers through the programmes.

The purpose of the study was to determine the adoption levels of farmers in cocoa rehabilitation techniques/resuscitation programmes in south-west, Nigeria and also ascertain the farmers' perception of the helpfulness of the relevant agencies in the consideration and adoption of cocoa rehabilitation techniques/resuscitation programmes.

\section{MATERIALS AND METHODS}

The study was carried out in southwest Nigeria. It lies between latitudes $5^{\circ}$ and $9^{\circ} \mathrm{N}$ of the equator and longitudes $2.5^{\circ}$ and $6^{\circ}$ east of the Greenwich Meridian. It is bounded by the Atlantic Ocean in the South, Kwara and Kogi states in the north, Anambra state in the Eastern Nigeria and Republic of Benin in the West. It has an area of $11.271 \mathrm{Km}^{2}$. All cocoa farmers in south-west Nigeria constituted the population for the study. A multistage sampling technique was employed in the selection of the respondents. Presently, five out of the six states in south west Nigeria produce cocoa and they are grouped into high (Ondo and Osun) and medium producing (Ogun, Oyo, and Ekiti) states. The two high cocoa producing states (Ondo and Osun) were selected for the study because of their significant contributions to cocoa production in Nigeria, while Ekiti State was randomly selected using simple random technique from the medium producing states. Hence, a total of three cocoa producing states (Ondo, Osun, and Ekiti) were selected for the study. From each of the three states (Ondo, Osun, and Ekiti) selected for the study, 
two high cocoa producing local government areas (LGAs) were purposively selected, giving a total of six LGAs for the study. These six high cocoa producing LGAs were: Idanre and Ondo East LGAs in Ondo State; Ife-East and Atakumosa-West LGAs in Osun State and Gbonyin and Ise/Orun LGAs in Ekiti State.

From each of the six LGAs selected for the study, a list of 10 high cocoa producing villages was obtained through a literature review of the previous published papers that ascertained those LGAs were high cocoa producing areas. From the list, four villages were selected through simple random sampling technique, producing 24 villages for the study (i.e. eight villages per state). From each of the 24 villages, a list of registered 10 cocoa farmers was collected from the Cocoa Farmers' Association and cooperative society of the selected villages through the help of Agricultural Development Programme (ADP) extension staff. From the list, 5 government beneficiary cocoa farmers and non-government beneficiary cocoa farmers were selected through simple random sampling technique. This gave a total of 120 government beneficiary cocoa farmers and 120 non-government beneficiary cocoa farmers respectively. Thus, a sample size of 240 cocoa farmers were involved in the study. Out of the total number of 240 cocoa beneficiary farmers sampled (i.e. 120 beneficiaries from the government CRPs and 120 from Olam CRPs), only 100 respondents (representing $41.7 \%$ of the total sampled beneficiaries) asserted that they benefitted only from the government CRPs, while 92 respondents (representing 38.3\% of the total sampled beneficiaries) benefitted only from non-governmental CRPs (Olam Nigeria Limitted, ONLs). The remaining 48 respondents (representing $20.0 \%$ of the total sampled beneficiaries) benefitted from both government and Olam CRPs. Data for the study were collected from the respondents through the use of structured interview schedule and focus group discussion (FGD) and questionnaire.

To determine the adoption levels of the various cocoa rehabilitation programmes introduced to the farmers, a 5-point Likert type adoption scale was used. The farmers were asked to indicate their adoption stage on the 5-point adoption scale. Their response categories and the corresponding weighted value were: awareness $=1$, interest $=2$, evaluation $=3$, trial $=4$, adoption $=5$. The total mean adoption score was computed by dividing the total adoption score by the number of respondents involved. Grand mean adoption score was calculated by adding all the mean adoption scores and dividing them by the number of innovations considered. The adoption index was carried out by dividing the grand mean adoption score by 5 (i.e. the 5 stages of adoption). The adoption index was later categorized into low and high. Adoption index of less than 50\% was considered as low and adoption index of 50\% and above was considered high.

To ascertain beneficiaries' perception of the helpfulness of the programme in the adoption of cocoa improved technologies, cocoa farmers were asked to indicate the extent of helpfulness of each of the agencies in the consideration and adoption of cocoa rehabilitation programmes. The modified rating technique was used in the study. The response categories and their corresponding scores were: of no help $=0$; of little help $=1 ;$ more helpful $=2 ;$ most helpful $=3$. Based on the responses of the farmers, the helpfulness scores of the agencies was added to get a value of 6.0 which was divided by 4 , to get a mean score (x) of 1.5. Variable of mean score $\geq 1.5$ was regarded as helpful, while variable $<1.5$ was regarded as not 
helpful in the consideration and adoption of cocoa rehabilitation programmes.

\section{RESULTS AND DISCUSSION}

\section{Adoption levels}

The adoption levels of the different types of cocoa rehabilitation techniques /resuscitation programmes disseminated by government and non-governmental agencies and practiced by cocoa farmers in South-West Nigeria as revealed in Table 1 are: coppicing, phase re-planting, planting of young cocoa seedling under old cocoa trees, complete replanting and selective planting (gapping up).

\section{Coppicing technique}

Coppicing technique is carried out in cocoa farms by complete removal of the main stem of cocoa using chain saw or cutlasses at $30 \mathrm{~cm}$ and above the ground level at a slightly oblique angle while the cut surface is painted with red paint to prevent termite attack. Results in Table 1 revealed that the adoption index for government beneficiary farmers was $34.0 \%$, for nongovernment beneficiary cocoa farmers was $32.0 \%$ and for both government and nongovernment beneficiary farmers was $33.0 \%$, respectively. These findings implied that the farmers had low adoption in coppicing technique. The reason for this observation was not unconnected with the fact that the technique (coppicing) was not allowing the farmers to easily embark on planting new cocoa cultivars that had higher yielding capacities and other desirable characteristics (e.g. resistance to diseases). A similar observation was made by Adeogun et al. (2010), that the adoption level of coppicing by cocoa farmers from selected states of
Nigeria was relatively low (31\%). Adebiyi \& Okunlola (2013) also found that only $10.6 \%$ of the respondents sampled in Oyo state adopted chupon regeneration/ coppicing.

\section{Phase-replanting techniques}

Phase replanting technique is recommended in cocoa farms if only part of the farm has been identified to be giving low yield, or farmers cannot afford the cost of replanting the entire cocoa plantation at once. The cocoa farm could be divided into three and the replanting exercise could be spread over three years. If these procedures were followed, the cocoa trees planted on the first part of the farm would have started producing by the time the farmer starts re-planting the last one-third of his farm. Thus, the farmer does not experience total loss of production during the period of phased replanting. The result in Table 1 showed that the adoption index for government beneficiary cocoa farmers, nongovernment beneficiary cocoa farmers and both government and non-government beneficiary farmers were $56.0 \%, 60.0 \%$ and $62.0 \%$, respectively. This implied that the adoption level of the farmers under phase replanting was high. This is contrary to Oluyole et al. (2015) findings that, only $10.6 \%$ of the farmers adopted phased planting in cocoa rehabilitation techniques in four cocoa producing States (Ondo, Cross River, Osun, and Ogun) in Nigeria. Phase replanting is expensive and usually not affordable to small scale farmers. As noted by Adesiyan et al. (2019), cocoa is one of the capital intensive businesses especially when it comes to the purchase of improved seedlings, particularly for women with limited or no fund for investment. 


\section{Planting seedlings under old trees}

Planting of young cocoa seedlings under old trees is recommended on cocoa farm with low yielding varieties or where cocoa trees are too old. The approach allows cocoa seedlings of improved varieties to be planted between old cocoa trees. The old and new trees are allowed to grow together, but the pruning of the old trees is done regularly to discourage growth and spread of black pod disease and allow sunlight to reach the young cocoa trees. The old trees are carefully cut down using a chainsaw or sharp cutlass immediately before the newly planted trees start fruiting.

It is also evident from the result in Table 1 that the adoption index for the five improved practices (planting of seedlings between mature stands in the morning and/or in the evening; use of recommended planting distance - $3.1 \mathrm{~m} \times 3.1 \mathrm{~m}$; application of herbicides where and/or when necessary; thorough weeding of the farm to ensure growth of seedlings without unnecessary competition for nutrients; and terracing against fire outbreak) for government beneficiary cocoa farmers, non-government beneficiary cocoa farmers and both government and nongovernment beneficiary farmers were $98.0 \%$, $94.0 \%$ and $95.0 \%$, respectively. This implies that the adoption level of the farmers was high. Nearly all the farmers adopted each of the improved five practices. This finding is in agreement with Adeogun et al. (2010) who found that the adoption level of planting young cocoa seedlings under old cocoa trees was as high as $85 \%$ from selected States in Nigeria. According to Oluyole et al. (2015), of all the adopted techniques, planting under old cocoa trees is mostly adopted cocoa rehabilitation techniques in four cocoa producing States (Ondo, Cross River, Osun, and Ogun) in Nigeria.

\section{Complete replanting}

Complete replanting is recommended on cocoa farm if the plot is affected by swollen shoot disease, especially in the area of mass infection, or if the trees have exceeded their productive age. The diseased or old trees should be cut down with a chainsaw or cutlasses. Uprooting cocoa trees with a bulldozer carries the risk of destroying all the organic matter in the soil, thereby encouraging leaching of nutrients and damaging the structure of the surface horizons of the soil. After the removal of the old trees, seedlings of improved varieties can be planted to replace them. Result in Table 1 revealed that the adoption index for the government beneficiary, non-government beneficiary and both government and nongovernment beneficiary farmers were $25.0 \%$, $27.0 \%$ and $26.0 \%$, respectively. This showed that the adoption level of the farmers in complete replanting was low. This finding is similar to the finding of Oluyole et al. (2015). In their findings, only 5.7\% of the farmers adopted complete replanting of cocoa rehabilitation techniques in four cocoa producing States in Nigeria.

\section{Selective planting}

Selective planting or gapping up in cocoa farms is the process that involves cutting out unprofitable cocoa trees, and then replanting them with improved varieties close to where the unprofitable cocoa trees have been removed. Selective planting or gapping up is recommended if the population acreage has fallen below $80 \%$ or if most of the cocoa trees have been found to be unproductive for over six years. Result in Table 1 showed that the adoption index for the government beneficiary, non-government beneficiary and both government and non-government beneficiary farmers were $68.0 \%, 81.0 \%$ and $79.0 \%$, 
Table 1. Adoption levels of cocoa resuscitation programme disseminated by government and non-governmental agencies in South West Nigeria

\begin{tabular}{|c|c|c|c|c|c|c|}
\hline \multirow[t]{2}{*}{ Cocoa resuscitation programme } & \multicolumn{2}{|c|}{$\begin{array}{l}\text { Beneficiary of } \\
\text { government's CRP } \\
\quad(n=100)\end{array}$} & \multicolumn{2}{|c|}{$\begin{array}{c}\text { Beneficiary of } \\
\text { non-governmental } \\
\text { agencies CRP } \\
(\mathrm{n}=92)\end{array}$} & \multicolumn{2}{|c|}{$\begin{array}{l}\text { Beneficiary of both } \\
\text { government and } \\
\text { non-governmental } \\
\text { CRP }(n=48)\end{array}$} \\
\hline & $\begin{array}{c}\text { Adoption } \\
\text { score }\end{array}$ & $\begin{array}{l}\text { Adoption } \\
\text { index }(\%)\end{array}$ & $\begin{array}{l}\text { Adoption } \\
\text { score }\end{array}$ & $\begin{array}{l}\text { Adoption } \\
\text { index }(\%)\end{array}$ & $\begin{array}{l}\text { Adoption } \\
\text { score }\end{array}$ & $\begin{array}{l}\text { Adoption } \\
\text { index }(\%)\end{array}$ \\
\hline \multicolumn{7}{|l|}{ Coppicing } \\
\hline $\begin{array}{l}\text { Cutting of the cocoa tree of } 30 \mathrm{~cm} \text { above ground } \\
\text { level using chain saw or cutlass and painting of } \\
\text { the surface of the coppiced three with red paint } \\
\text { to prevent termite attract }\end{array}$ & 1.70 & 34 & 1.47 & 32 & 1.65 & 33 \\
\hline \multicolumn{7}{|l|}{ Phased Replanting } \\
\hline $\begin{array}{l}\text { Dividing cocoa farms into } 3 \text { or } 4 \text { parts for phase } \\
\text { replanting and planting with hybrid cocoa seedlings }\end{array}$ & 2.81 & 56 & 2.78 & 60 & 3.10 & 62 \\
\hline \multicolumn{7}{|l|}{ Planting Seedlings Under Old Cocoa Trees } \\
\hline $\begin{array}{l}\text { Planting of the seedling between mature tree stand } \\
\text { (in the morning or late at night) }\end{array}$ & 4.76 & 89 & 4.30 & 94 & 4.79 & 95 \\
\hline $\begin{array}{l}\text { Using recommended planting distance } \\
\text { (spacing of } 3.1 \mathrm{~m} \times 3.1 \mathrm{~m} \text { ) }\end{array}$ & 4.80 & & 4.29 & & 4.52 & \\
\hline Application of herbicides (where necessary) & 4.83 & & 4.34 & & 4.65 & \\
\hline Weeding whole farm to ensure seedlings growth & 4.93 & & 4.29 & & 4.92 & \\
\hline Fire outbreak (Terracing) & 4.97 & & 4.32 & & 4.77 & \\
\hline \multicolumn{7}{|l|}{ Complete Replanting } \\
\hline $\begin{array}{l}\text { Complete clearing of cocoa farms affected by } \\
\text { disease or old age and planting with improved } \\
\text { cocoa seedlings }\end{array}$ & 1.24 & 25 & 1.26 & 27 & 1.31 & 26 \\
\hline \multicolumn{7}{|l|}{ Selective Planting (Grapping Up) } \\
\hline $\begin{array}{l}\text { Cutting down unprofitable coca trees and } \\
\text { replanting with improved variety close to where } \\
\text { unprofitable trees have been removed }\end{array}$ & 3.06 & 68 & 4.02 & 81 & 4.10 & 79 \\
\hline Fertilizer application (where necessary) & 2.19 & & 2.77 & & 2.92 & \\
\hline Pruning of old trees to allow aeration & 4.91 & & 4.38 & & 4.81 & \\
\hline
\end{tabular}

Note: Adoption index of $>50 \%$ is high adoption; Adoption index of $\leq 50 \%$ is low adoption

respectively, implying that the adoption level of the farmers was high. This finding is in contrast to the findings of Oluyole et al. (2015) that only $4.2 \%$ of the cocoa farmers adopted partial replanting of cocoa rehabilitation techniques in four cocoa producing states in Nigeria.

\section{Farmers perception of agency helpfulness}

This section describes the extent to which cocoa farmers' adoption of the cocoa rehabilitation techniques/resuscitation programmes could be attributed-directly or indirectly to the activities of the different agencies involved in cocoa activities. Results in Table 2 revealed that all the governmental and non-governmental agencies were helpful in the adoption of cocoa rehabilitation techniques/resuscitation programmes. The most helpful agency in the adoption of cocoa rehabilitation techniques/ resuscitation programmes was $\mathrm{ADP}(\mathrm{x}=2.80)$. During the focus group discussion, the respondents asserted that some of the extension activities conducted by the ADP to rekindle and sustain the interest of the cocoa farmers included: provision of information on cocoa production and management techniques, provision of free cocoa hybrid seedlings and 
Table 2. Perception of the cocoa farmers on helpfulness of agencies in the adoption of cocoa rehabilitation techniques/resuscitation programmes

\begin{tabular}{lccc}
\hline Group of farmers & $\begin{array}{c}\text { Government } \\
\text { beneficiaries } \\
(\mathrm{n}=100)\end{array}$ & $\begin{array}{c}\text { Nongovernmental } \\
\text { beneficiaries } \\
(\mathrm{n}=92)\end{array}$ & $\begin{array}{c}\text { Both } \\
\text { and } \begin{array}{c}\text { government } \\
\text { government } \\
\text { beneficiaries }(\mathrm{n}=48)\end{array}\end{array}$ \\
\hline Agencies & Mean (x) & Mean (x) & Mean (x) \\
\hline Cocoa Development Unit (CDU) & $1.54^{*}(1.15)$ & $0.24(0.52)$ & $1.60^{*}(1.00)$ \\
Cocoa Research Institute of Nigeria (CRIN) & $0.17(0.37)$ & $0.11(0.37)$ & $0.13(0.39)$ \\
Agricultural Development Programme (ADP) & $2.80^{*}(0.44)$ & $1.11(0.94)$ & $2.21^{*}(0.82)$ \\
National Cocoa Development Council (NCDC) & $0.08(0.27)$ & $0.12(0.35)$ & $0.04(0.20)$ \\
Farmers Development Union (FADU) & $0.43(0.57)$ & $0.20(0.57)$ & $0.25(0.56)$ \\
Olam Nigeria limited (ONLs) & $0.20(0.44)$ & $2.52^{*}(0.70)$ & $1.98^{*}(0.93)$ \\
Diocesan Agricultural Development Project (DADPO) & - & $0.09(0.38)$ & $0.04(0.20)$ \\
SARO Agro- Allied Limited & $0.01(0.10)$ & $1.58^{*}(1.26)$ & $1.56^{*}(1.12)$ \\
International Institute for Tropical Agriculture (IITA) & $0.27(0.48)$ & $0.11(0.37)$ & $0.02(0.14)$ \\
Justice and Peace Development Commission (JPDC) & - & $0.07(0.32)$ & $0.02(0.14)$ \\
Cooperation Multipurpose Union (CMU) & $0.40(0.72)$ & $1.41(1.23)$ & $1.13(1.16)$ \\
\hline Notes: Figure in parenthesis means standard deviation; & & &
\end{tabular}

specialized short training courses for farmers on harvest, breaking techniques, fermentation, drying, grading and marketing techniques.

Another agency that was considered useful in the consideration and adoption of cocoa rehabilitation techniques/resuscitation programmes as perceived by government beneficiary cocoa farmers was Cocoa Development Unit [CDU] $(\mathrm{x}=1.54)$. The CDU was established in each of the cocoa producing states in south west Nigeria. The CDU of each cocoa producing state's ministry of agriculture has the roles of linking up with Cocoa Research Institute of Nigeria [CRIN] in supplying pods from improved materials for the establishment of these seed gardens, hence ensuring that cocoa materials supplied to farmers are reliable, providing extension agents to assist farmers with appropriate ways of rehabilitating their cocoa farms, providing other inputs such as chemicals to cocoa farmers for the purpose of rehabilitating cocoa farms, serving as the channel for distribution of inputs for cocoa rehabilitation. This finding is supported by Adetunji et al. (2007), who found that $30.0 \%$ of the cocoa farmers in Oyo state claimed to have improved their knowledge of cocoa production through CDU activities.

Results in Table 2 further revealed that non-government beneficiary cocoa farmers indicated that Olam Nigeria Ltd $(x=2.52)$ was most helpful in the consideration and adoption of cocoa rehabilitation techniques/ resuscitation programmes. The fact that Olam was rated as most useful non-governmental organization in adoption of cocoa rehabilitation techniques/resuscitation programmes corroborates with the finding of Akinnagbe \& Ajayi (2012). According to the finding, Olam revived old farm settlements and model farms, trained farmers on improved agronomic practices and provided their model farmers with hybrid seedlings. Olam, a private, commercial and multi-product company was established in 1989 by the Kewalram Chanrai Group (KCG), with its headquarters in Singapore and principal office in Lagos, Its regional offices are found in Kano and Akure. It provides what could be called specialized extension services and uses specific agricultural products (such as cocoa, coffee, cashew, sheanuts, sesame, rice, and teak wood) as industrial materials. 
Its cocoa business began in Nigeria in 1992 and has participated in all aspects of cocoa business like production, marketing and processing, in the cocoa-producing states such as Ondo, Osun, Ekiti, Edo, Ogun, Cross River, Taraba, and Adamawa. Another agency that was considered useful was Saro Agro Chemical Limited $(x=1.58)$. There is need for government extension agency to coordinate all these other agencies in the rural areas to ensure unity of purpose and cooperation to avoid unnecessary rivalry and conflicts and duplication of efforts among the agencies.

\section{Socio-economic aspiration indices}

Aspirations, defined as an individual's desire to achieve a goal or an objective, or a strong desire for betterment, are key factors affecting future-oriented decision behaviour including investment (Bernard et al., 2014). Figure 1 shows the aspiration indices of cocoa farmers. The farmers (government beneficiary cocoa farmers, non-government beneficiary cocoa farmers and both government and non-government beneficiary farmers) were asked this question: "Suppose you suddenly acquire an income of " $x$ " naira, what would you spend it on?" The responses of the farmers were presented in Figure 1. Majority (82.9\%) of the beneficiary cocoa farmers asserted that they would have used the money for the improvement of their existing cocoa farms (employment of more labour for farm activities, purchase of improved seedlings, fungicides and insecticides), while $70.8 \%$ of the beneficiary cocoa farmers asserted that the amount would have been to acquire more cocoa farms to increase the hectare of cocoa farm to be cultivated.

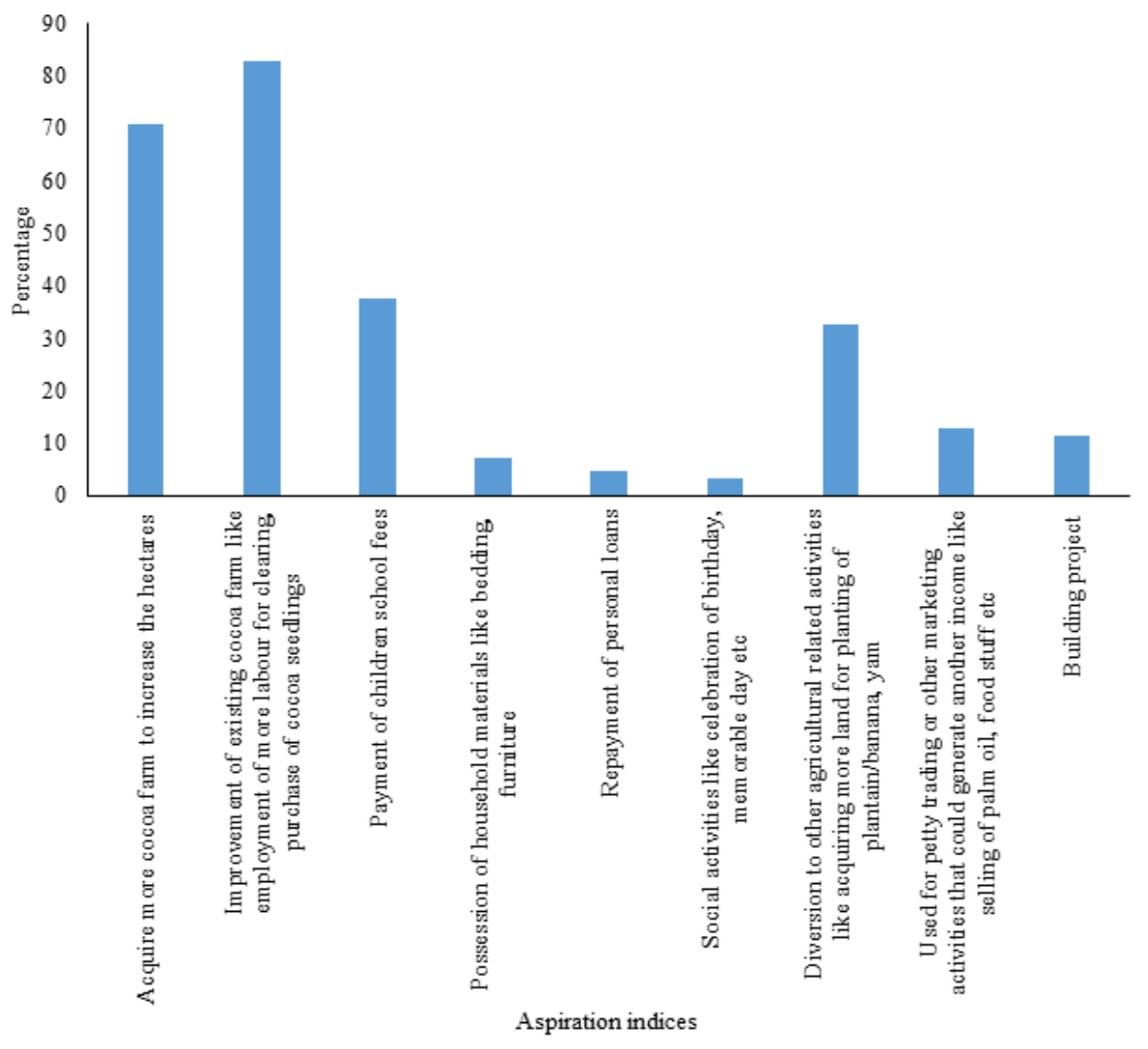

Figure 1. Socio-economic aspiration indices of cocoa farmers 
The result above is in support of the assertion of Mojo et al. (2016), that aspirations motivate behaviours, serve to mobilize and direct energy into actions, and are regarded as important determinants of success. Farmers' aspirations serve to mobilise them into their goal of increasing the hectares of cocoa farm to produce more. It reflects the extent to which poor people feel that they have control over their future.

The percentage of the beneficiary farmers that asserted that they would have used the money for payment of their children's school fees $(37.5 \%)$ and diversion to other agricultural activities like planting of plantain and banana, and yam (32.5\%) was very low. The farmers also asserted that they would have used the money for the following area of interest; pretty trading and other marketing activities that could generate another income (12.9\%), building project (11.3\%), possession of household materials like radio, television, bedding, furniture (7.1\%), repayment of personal loan $(4.6 \%)$, converting the money into social activities like celebration of birthday, memorable day. This is a clear indication that cocoa farmers wanted to quantitatively and qualitatively improve their cocoa farms. Better improvement for cocoa farms would increase yield and hence, more cash, which could be used to meet other rising needs.

\section{CONCLUSIONS}

Farmers were at the different level of the adoption process of cocoa rehabilitation techniques/resuscitation programmes in south-west Nigeria. The adoption of coppicing techniques and complete replanting of cocoa rehabilitation programme was low. Planting of young cocoa seedling under old cocoa trees, phase replanting and selective planting (gapping up) had high adoption level. Implying that majority of the farmers had adopted some of the improved practices of planting young cocoa seedlings under old cocoa trees. The most helpful agencies as perceived by the farmers in the adoption of the government improved cocoa rehabilitation techniques/resuscitation programmes were agricultural development programme and cocoa development unit, while that of non-governmental agencies cocoa rehabilitation techniques/resuscitation programmes were Olam Nigeria and Saro Agro Allied Limited. To improve the level of adoption of cocoa rehabilitation programmes, the federal government of Nigeria should further intensify efforts in encouraging more farmers in cocoa rehabilitation programme by providing the necessary incentives (like distribution of free cocoa seedlings) to the farmers as at when necessary.

\section{REFERENCES}

Adebiyi, S. \& J.O. Okunlola (2013). Factors affecting adoption of cocoa farm rehabilitation techniques in Oyo State of Nigeria. World Journal of Agricultural Sciences, 9, 258-265.

Adeniyi, D. (2019). Diversity of cacao pathogens and impact on yield and global production, - Deploying Science for sustainability of global cocoa economy, p. 1-20. In: Theobroma Cacao (Peter Aikpokpodion, Ed.). Intech Open, London, UK.

Adeogun, S.O.; J.E. Olawoye \& L.A. Akinbile (2010). Information sources to cocoa farmers on cocoa rehabilitation techniques (CRTs) in selected states of Nigeria. Journal Media and Communication Studies, 2, 009-015.

Adesiyan, O.F.; A.T. Adesiyan \& M. Agbonlahor (2019). Adoption of cocoa input technologies under agricultural transformation agenda among women cocoa farmers in Ile-Ife, Osun State. Journal of Development and Agricultural Economics, 11, $52-56$. 
Adetunji, M.O.; O.A. Olaniyi \& M.O. Raufu (2007). Assessment of benefits derived by cocoa farmers from cocoa development Unit Activities of Oyo State. Journal of Human Ecology, 22, 211-214.

Akinnagbe, O.M. \& A.R. Ajayi (2012). Impact of Olam organization extension programme on socio-economic life of cocoa farmers in Ondo state, Nigeria. Journal of Agricultural Extension and Rural Development, 4, 30-40.

Bernard, T. \& A.S. Taffesse (2014). Aspirations: an approach to measurement with validation using Ethiopian data. Journal of African Economies, 23, 189-224.

Camargo, M. \& I. Nhantumbo (2016). Towards Sustainable Chocolate: Greening the Cocoa Supply Chain. IIED, London.

FAO (2017). Production Quantities of Cocoa, Beans by Country, Average 1994-2017. Food and Agriculture Organization of the United Nations (FAO) FAO, Rome.
Mojo, D.; C. Fischer \& T. Degefa (2016). Collective action and aspirations: the impact of cooperatives on Ethiopian coffee farmers' aspirations. Annals of Public and Cooperative Economics, 87, 217-238.

Oluyole, K.A; A.O. Famaye; S.O. Agbeniyi; M.O. Ogunlade; A.A. Oloyede; P.E. Aikpokpodion; S.B. Orisajo \& K.B. Adejobi (2015). Evaluation of the practices of cocoa rehabilitation techniques among cocoa farmers in Nigeria. Global Journal of Agricultural Economics, Extension and Rural Development, 3, 188-193.

Schroth, G.; P. Läderach; A.I. Martinez-Valle \& C. Bunn (2017). From site-level to regional adaptation planning for tropical commodities: cocoa in West Africa. Mitigation and Adaptation Strategies for Global Change, 22, 903-927. 